RESEARCH ARTICLE

\title{
Effects of hospitalization on children's sleep pattern irrespective of sleep problems history
}

\author{
Maite Farías-Fernández ${ }^{1}$, Mario E. Rendón-Macías²*, José Iglesias-Leboreiro³, Isabel Bernárdez-Zapata³, \\ and Lucina Gordillo-Rodríguez ${ }^{1}$
}

${ }^{1}$ Facultad Mexicana de Medicina, Universidad La Salle México; ${ }^{2}$ Escuela de Medicina, Universidad Panamericana; ${ }^{3} \mathrm{Hospital}$ Español de México. Mexico City, Mexico

\begin{abstract}
Background: Sleep is a neurophysiologic process necessary for brain development. However, sleep patterns change with aging. This study aimed to compare the sleep pattern in pediatric patients with and with no previous sleep problems (PSP) during the first 48 hours of hospitalization and analyze the factors influencing sleep disruption. Methods: We conducted a prospective cohort study. Under informed consent, two groups of patients < 17 years admitted to a hospital for acute illnesses were followed. The history of PSP was determined with the Brief sleep questionnaire. For 48 hours, the sleep pattern was observed in terms of total hours of daily sleep, daytime naps, night awakenings, and time to fall asleep. We recorded actions of attention associated with sleep time. Results: Patients with PSP showed an increased total duration of sleep hours per day by an average of one hour, improving the sleep pattern. In patients with no PSP, the total hours of sleep diminished transitorily and the time elapsed to initiate sleep, the number of daytime naps, and night awakenings increased. Alarms sound, the presence of vein catheters and tubes, and the entry and exit of healthcare personnel to the rooms were identified as critical factors of sleep interruptions. Conclusions: Hospitalization alters sleep patterns, especially in children without previous sleep problems. We recommend exploring sleep patterns in all hospitalized children and reducing external factors associated with their disturbance as much as possible.
\end{abstract}

Keywords: Sleep. Hospitalization. Sleep disorders.

\section{Efectos de la hospitalización en el patrón del sueño en niños independientemente de antecedentes de problemas del sueño}

\section{Resumen}

Introducción: El sueño es un proceso neurofisiológico necesario para el desarrollo cerebral cuyos patrones varían con la edad. El objetivo de este estudio fue comparar el comportamiento del patrón del sueño en niños con y sin problemas previos del sueño (PPS) durante las primeras 48 horas de hospitalización, y analizar los factores influyentes en la interrupción del sueño. Métodos: Se realizó un estudio de cohorte prospectivo. Con el consentimiento informado, se siguieron dos grupos de pacientes < 17 años ingresados al área de hospitalización por diversas enfermedades agudas. El antecedente de PPS se determinó con el Cuestionario breve del sueño. El patrón del sueño se observó por 48 horas y se registraron las horas

\section{Correspondence:}

*Mario E. Rendón-Macías

E-mail: mrendon@up.edu.mx
Date of reception: 03-09-2020

Date of acceptance: $10-11-2020$

DOI: 10.24875/BMHIM.20000277
Available online: $23-07-2021$

Bol Med Hosp Infant Mex. 2021;78(4):279-286 www.bmhim.com (http://creativecommons.org/licenses/by-nc-nd/4.0/). 
totales de sueño diario, los minutos para conciliar el sueño nocturno, los minutos de despertares nocturnos y las siestas diurnas. Se registraron las acciones médicas asociadas con el tiempo de sueño. Resultados: En promedio, la duración total de las horas de sueño por día aumentó una hora en los pacientes con PPS, mejorando la higiene de sueño en este grupo. En el grupo de niños sin PPS se observó una disminución transitoria de las horas totales de sueño y un incremento en el tiempo para dormirse, los minutos de siestas diurnas y las vigilias nocturnas. El sonido de las alarmas, la colocación de venoclisis y de sondas de drenaje, así como la entrada y salida del personal de salud a las habitaciones, fueron identificados como factores de interrupción del sueño. Conclusiones: La hospitalización altera los patrones del sueño, sobre todo en niños sin problemas previos del sueño. Se recomienda explorar los patrones del sueño en los niños hospitalizados $y$ reducir, en lo posible, los factores externos asociados a su perturbación.

Palabras clave: Sueño. Hospitalización. Trastornos del sueño.

\section{Introduction}

Sleep is a neurophysiological process necessary for brain development whose patterns vary with age; during the first year of life, the average sleep time is 12 to 16 hours, decreasing to 11 to 14 hours in infants, 10 to 13 hours in preschoolers, 9 to 12 hours in school children and 8 to 10 hours in adolescents $<19$ years of age ${ }^{1}$. As the child grows and matures, a sleep pattern similar to that of an adult is taken: shorter durations, longer sleep cycles, and less daytime sleep. Most children stop taking regular naps around 5 years of age $\mathrm{e}^{1,2}$.

In pediatric patients, parental surveys estimate a prevalence of approximately $30 \%$ of sleep pattern problems, reported as problems in falling asleep or maintaining sleep at the appropriate time at night ${ }^{2}$.

Several factors alter sleep behavior: hospitalization is one of them. In this condition, environmental factors such as alarms, invasive procedures, physical examinations, vital signs monitoring, different beds or cradles, among others, together with personal factors, such as the disease itself, can affect and have repercussions on the quality and quantity of sleep ${ }^{3}$.

Although sleep disturbances in hospitalized children have been studied, whether these disturbances occur more frequently because these children already have previous sleep disturbances has not been analyzed. We hypothesize that children who present sleep disturbances during the in-hospital stay are usually children who, although they have not been identified or diagnosed, already have a history of sleep problems at home.

This study aimed to analyze sleep behavior in pediatric patients with and with no previous sleep problems (PSP) during the first 48 hours of in-hospital stay. The hypothesis was that sleep behavior would be more affected in the first group of patients. Secondarily, we also analyzed environmental factors associated with sleep pattern modification.

\section{Methods}

\section{Study design}

We conducted a prospective cohort study on sleep pattern behavior in hospitalized children with or with no previous sleep disturbances. The sample was obtained by convenience among those patients admitted to the hospital from January to April 2019. The study included previously healthy patients $<17$ years of age of either sex. Patients with a history of previous neurological disorders, genetic syndromes, and those admitted to intensive care or neonatal intensive care units were excluded.

To determine the history of PSP in children before hospitalization, we applied the brief sleep questionnaire through direct questioning of the parents or guardians. This questionnaire consists of 10 questions about the usual sleep pattern at home and looks for criteria to establish a sleep disorder ${ }^{4}$. Two of the following three criteria must be met to define PSP: sleep duration $<8$ hours in 24 hours, three or more nocturnal awakenings in one night, and requiring more than one hour for falling asleep.

After establishing the history of sleep problems and once the child was hospitalized, the sleep pattern was monitored daily through a diary. The sleep diary consisted of nine questions to the parents or guardians: bedtime, time to fall asleep (from lying down to the moment of perception of deep sleep), number and time of nocturnal awakenings, the wake-up time in the morning, and the number and duration of daytime naps. Data were collected by one of the physicians (MFF). With the information on day and night sleep times, the total daily sleep time was calculated. Also, a record of the items present during each day in the child's care was made. We also collected information on patients' age, sex, and the reason of their hospitalization. 


\section{Statistical analysis}

The patients were divided into two groups: PSP and no PSP groups. The qualitative variables were summarized in simple frequencies and percentages, while quantitative variables were summarized according to data distribution in means and standard deviations (SD) or medians with quartiles (Q1-Q3). $\chi^{2}$-test was used to compare the qualitative variables between groups. The two-factor repeated-measures analysis of variance (ANOVA) (difference over time and difference between groups) was used to analyze the behavior between groups at different times when the data distribution was normal; the Mann Whitney's U-test (between groups) and the Wilcoxon signed-rank test for baseline vs. $24 \mathrm{~h}$ and $48 \mathrm{~h}$ differences were used when the distribution was not normal. Multiple linear regression was performed to determine the factors related to the change in sleep patterns, adjusting all factors with the history of sleep problems; the dependent variable was the duration of sleep pattern analyzed at $24 \mathrm{~h}$ and $48 \mathrm{~h}$. Jeffrey's Amazing Statistic Program (JASP) was used, and $p$-values $<0.05$ were considered statistically significant. The Bioethics Committee of the hospital approved the project with file number ENS 2020T001. The signed informed consent form was obtained from the parents.

\section{Results}

During the study period, 120 children met our selection criteria: 24 patients $(20 \%)$ met the criteria to be considered in the PSP group before hospitalization (Table 1). We found no statistical differences among sex, age, admission cause, and the use of most gadgets. The exception was the continuous use of the pulse oximeter $(p<0.005)$. In most patients $(65.8 \%)$, acute respiratory and gastrointestinal tract diseases were the main reason for medical care.

\section{Sleep pattern behavior during hospitalization}

We found differences between the PSP and the no PSP groups during the three days of in-hospital sleep pattern monitoring. Regarding the total duration of sleep during the day before hospitalization (Figure 1), the group with PSP slept on average 7.7 hours $( \pm 1.7 \mathrm{~h}$ ) versus 9.5 hours $( \pm 1.4 \mathrm{~h}, p=0.001)$ in the group with no PSP. We found that the sleep time during hospitalization increased in the group with PSP a mean of one hour more per day (at $24 \mathrm{~h}: 8.4 \pm 1.8 \mathrm{~h}$, and at $48 \mathrm{~h}: 9.3 \pm 2 \mathrm{~h}, p=0.0006$ ) (Table 2). Conversely, the total sleep time decreased by
Table 1. Characteristics of patients regarding sleep problems before hospitalization

\begin{tabular}{|c|c|c|}
\hline Characteristics & $\begin{array}{c}\text { PSP }(n=24) \\
n(\%)\end{array}$ & $\begin{array}{c}\text { No PSP }(n=96) \\
n(\%)\end{array}$ \\
\hline $\begin{array}{l}\text { Sex } \\
\text { Male } \\
\text { Female }\end{array}$ & $\begin{array}{l}13(54.7) \\
11(45.2)\end{array}$ & $\begin{array}{l}50(52.1) \\
46(47.9)\end{array}$ \\
\hline $\begin{array}{l}\text { Age group } \\
\text { Infants } \\
\text { Preschoolers } \\
\text { Schoolchildren and } \\
\text { adolescents }\end{array}$ & $\begin{array}{c}12(50.0) \\
3(12.5) \\
9(37.59)\end{array}$ & $\begin{array}{l}41(42.7) \\
24(25.0) \\
31(32.3)\end{array}$ \\
\hline $\begin{array}{l}\text { Diagnosis } \\
\text { Respiratory } \\
\text { Gastrointestinal } \\
\text { Surgical } \\
\text { Neurological } \\
\text { Trauma } \\
\text { Infectious }\end{array}$ & $\begin{array}{c}8(33.3) \\
7(29.2) \\
4(16.7) \\
4(16.7) \\
1(4.2) \\
0\end{array}$ & $\begin{array}{c}32(33.7) \\
27(28.4) \\
8(8.4) \\
6(6.3) \\
6(6.3) \\
16(16.8)\end{array}$ \\
\hline $\begin{array}{l}\text { Gadgets } \\
\text { Intravenous line } \\
\text { Nebulization } \\
\text { Cardiac monitor } \\
\text { Pulse oximeter } \\
\text { Humidifier } \\
\text { Drains or catheters } \\
\text { Splints } \\
\text { Pulmonary physiotherapy }\end{array}$ & $\begin{array}{c}22(91.7) \\
9(37.5) \\
7(29.2) \\
6(25.0) \\
3(12.5) \\
1(4.2) \\
0 \\
0\end{array}$ & $\begin{array}{l}89(92.7) \\
36(37.5) \\
8(8.3) * \\
25(26.0) \\
11(11.5) \\
4(4.2) \\
4(4.2) \\
5(5.2)\end{array}$ \\
\hline
\end{tabular}

PSP, previous sleep problems.

${ }^{*} \chi^{2} 7.62,1$ degree of freedom, $p=0.005$.

one hour at $24 \mathrm{~h}(8.5 \pm 2.4 \mathrm{~h})$ but recovered at $48 \mathrm{~h}$ $(9.9 \pm 3.3 \mathrm{~h})$ in children with no PSP (Figure 1).

The time to initiate sleep was consistently longer in children with PSP history ( $p=0.005$ ) (Figure 2). In this group, the mean time in minutes needed to fall asleep before hospitalization was $27.5 \mathrm{~min}$, while during hospitalization at $24 \mathrm{~h}$, the mean was $26.1 \mathrm{~min}$, and at $48 \mathrm{~h}$, it was $29.2 \mathrm{~min}(p=0.0001)$. In children with no PSP, the time was shorter; however, it increased during hospitalization: before hospitalization, the mean was $12.8 \mathrm{~min}$, while during hospitalization, the mean at $24 \mathrm{~h}$ was $20.4 \mathrm{~min}$ and at $48 \mathrm{~h}, 19.5 \mathrm{~min}$ ( $p=0.0001$ ) (Table 2).

Regarding nighttime awakenings, they were more frequent before hospitalization in children with PSP [median $1(\min =0, \max =7)]$ than the no PSP group [median 0 $(\min =0, \max =2](p<0.001)$. However, during hospitalization, more than $50 \%$ of children with no PSP woke up at least once during the night (median $24 \mathrm{h:} 1[0,10]$ and $48 \mathrm{h:} 1[0,8])$. Furthermore, the group with PSP had a median of one awakening with a maximum of $8 \mathrm{epi}-$ sodes (Mann Whitney's U-test between groups at $24 \mathrm{~h}$, $p=0.52$; at $48 \mathrm{~h}, p=0.77$ ). On most occasions, parents 
Table 2. Observed effects on the sleep pattern in hospitalized children

\begin{tabular}{|c|c|c|c|c|c|c|c|c|c|}
\hline & \multicolumn{3}{|c|}{ Before hospitalization } & \multicolumn{3}{|c|}{$0-24 h$} & \multicolumn{3}{|c|}{$0-48 \mathrm{~h}$} \\
\hline & PSP & No PSP & $\begin{array}{c}\text { Group } \\
\text { difference } \\
\text { (95\%CI) } \\
\text { p-value* }\end{array}$ & $\begin{array}{c}\text { PSP } \\
\text { difference } \\
\text { (95\%CI) } \\
\text { p-value** } \\
\text { Mean } \pm S E\end{array}$ & $\begin{array}{c}\text { No PSP } \\
\text { difference } \\
\text { (95\%CI) } \\
\text { p-value** } \\
\text { Mean } \pm \text { SE }\end{array}$ & $\begin{array}{c}\text { Group } \\
\text { difference } \\
\text { (95\%CI) } \\
\text { p-value* }\end{array}$ & $\begin{array}{c}\text { PSP } \\
\text { difference } \\
\text { (95\%CI) } \\
p \text {-value** } \\
\text { Mean } \pm S E\end{array}$ & $\begin{array}{c}\text { No PSP } \\
\text { difference } \\
\text { (95\%CI) } \\
\text { p-value** } \\
\text { Mean } \pm \text { SE }\end{array}$ & $\begin{array}{c}\text { Group } \\
\text { difference } \\
\text { (95\%CI) } \\
p \text {-value* }\end{array}$ \\
\hline $\begin{array}{l}\text { Hours of } \\
\text { sleep } \\
\text { per day } \\
\text { Mean } \pm \\
\text { SD }\end{array}$ & $7.7 \pm 1.7$ & $9.5 \pm 1.4$ & $\begin{array}{c}1.8 \\
(1.16-2.5) \\
<0.001\end{array}$ & $\begin{array}{c}0.74 \pm 0.4 \\
(0.2 ; 1.6) \\
<0.001 \\
8.4 \pm 0.3\end{array}$ & $\begin{array}{c}-1.01 \pm 0.3 \\
(-1.5 ;-0.47) \\
0.11 \\
8.5 \pm 0.2\end{array}$ & $\begin{array}{c}0.07 \\
(-0.9-1.1) \\
0.89\end{array}$ & $\begin{array}{c}2.3 \pm 0.47 \\
(1.2-3.2) \\
<0.001 \\
9.23 \pm 0.5\end{array}$ & $\begin{array}{c}0.4 \pm 0.46 \\
(-1.3-0.5) \\
0.41 \\
9.9 \pm 0.4\end{array}$ & $\begin{array}{c}0.6 \\
(-1.1-2.3) \\
0.85\end{array}$ \\
\hline $\begin{array}{l}\text { Minutes } \\
\text { to fall } \\
\text { asleep } \\
\text { Mean } \pm \\
\text { SD }\end{array}$ & $27.5 \pm 29$ & $12.8 \pm 10$ & $\begin{array}{c}-14.6 \\
(-22--7.2) \\
<0.001\end{array}$ & $\begin{array}{c}-1.3 \pm 9.3 \\
(-17.9-20.6) \\
0.89 \\
26.2 \pm 7.7\end{array}$ & $\begin{array}{c}7.5 \pm 3.4 \\
(0.8-14.2) \\
0.03 \\
20.3 \pm 3.4\end{array}$ & $\begin{array}{c}-5.7 \\
(-21.4-9.8) \\
0.47\end{array}$ & $\begin{array}{c}1.5 \pm 14 \\
(-31.7 \\
-28.7) \\
0.92 \\
29.2 \pm 14\end{array}$ & $\begin{array}{c}6.4 \pm 3.3 \\
(0.3-13.1) \\
0.06 \\
19.5 \pm 3.3\end{array}$ & $\begin{array}{c}-9.7 \\
(-28.8-9.4) \\
0.32\end{array}$ \\
\hline $\begin{array}{l}\text { Minutes } \\
\text { awake } \\
\text { at night } \\
\text { [med, } \\
\text { Q1-03] }\end{array}$ & $\begin{array}{c}10 \\
{[0.75-} \\
18.75]\end{array}$ & $\begin{array}{c}0 \\
{[0-10]}\end{array}$ & 0.01 & $\begin{array}{c}2.1 \\
(-12.5-18.5) \\
0.85 \\
10[4.5-16.2]\end{array}$ & $\begin{array}{c}4 \\
(0.002-7.5) \\
0.06 \\
5[0-15]\end{array}$ & 0.17 & $\begin{array}{c}3.75 \\
(-7-35) \\
0.35 \\
3[0-13.7]\end{array}$ & $\begin{array}{c}3 \\
(2.5-10) \\
0.24 \\
5[0-15]\end{array}$ & 0.28 \\
\hline $\begin{array}{l}\text { Daytime } \\
\text { naps } \\
\text { [med, } \\
\text { Q1-03] }\end{array}$ & $\begin{array}{c}1 \\
{[0-2]}\end{array}$ & $\begin{array}{c}0 \\
(0-1]\end{array}$ & $<0.001$ & $\begin{array}{c}0 \\
1.0 \\
0.5[0-2]\end{array}$ & $\begin{array}{c}0.8 \\
(-1.1-0.6) \\
0.85 \\
0[0-1]\end{array}$ & 0.70 & $\begin{array}{c}0 \\
1.0 \\
0.5[0-1.75]\end{array}$ & $\begin{array}{c}0.8 \\
(-1.1-0.6) \\
0.85 \\
1[0-2]\end{array}$ & 0.81 \\
\hline
\end{tabular}

*Independent groups t-test or Mann Whitney's U-test; ${ }^{* *}$ Student's t-test or Wilcoxon test (median and 95\% confidence intervals by Hodges-Lehman estimate), $p<0.05$ $\mathrm{Cl}$, confidence interval; med, median; Q1-03, first and third quartile; PSP, previous sleep problems; SD, standard deviation; $\mathrm{SE}$, standard error.

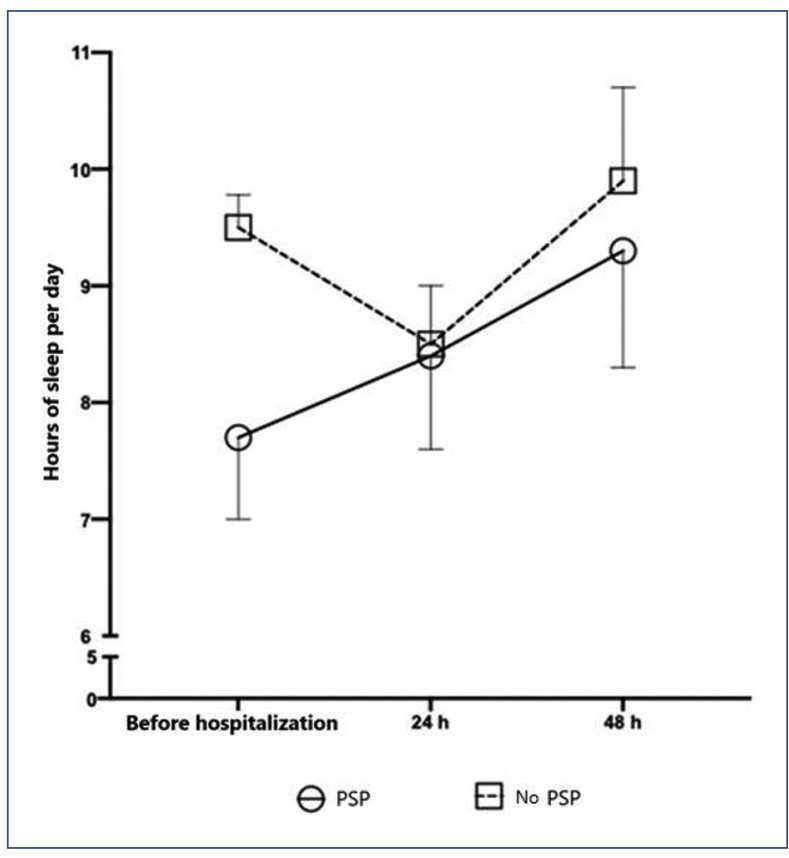

Figure 1. Hours of sleep per day before hospitalization and during the first 48 hours of hospitalization. Results are expressed as mean (symbols) \pm standard error (bars). ANOVA, $p=0.005$; effect over time, $p=0.32$; interaction between groups and time, $p=0.0006$.

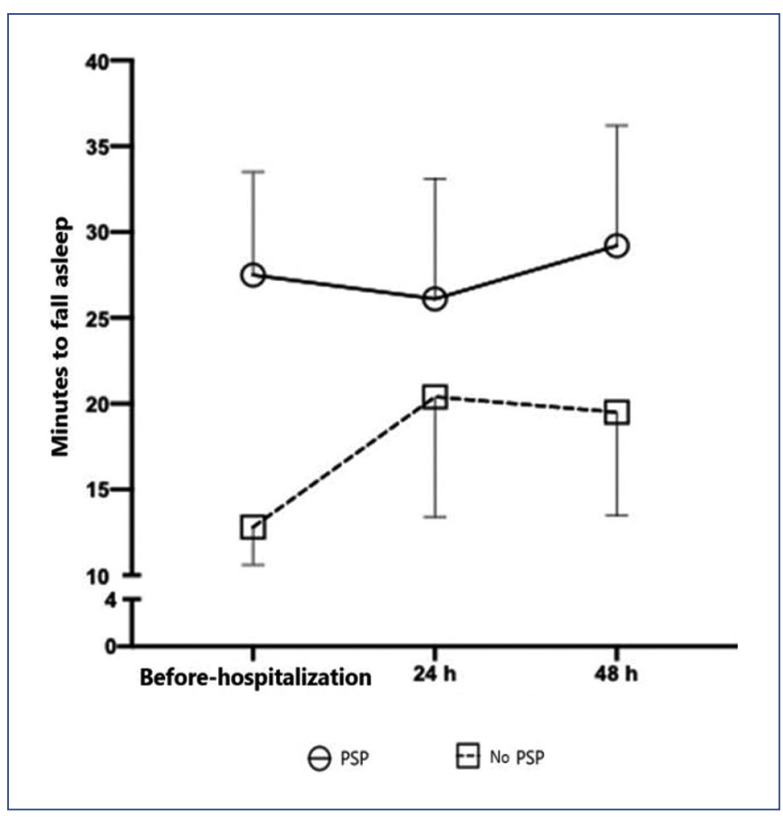

Figure 2. Minutes to fall asleep at night before hospitalization and during the first 48 hours of hospitalization. Results are expressed as mean (symbols) \pm standard error (bars). Two-way ANOVA, difference between groups $p=0.005$, effect over time, $p=0.0001$; interaction between groups and time, $p=0.0001$. 
attributed these awakenings to alarms, the entry of medical and nursing staff into the room, or the performance of nebulization and pulmonary therapy.

The distribution of the time spent awake at night did not show a normal distribution, so it was analyzed using medians (Figure 3). The median awake time at night before hospitalization in the PSP group was $10 \mathrm{~min}$, although it was reported that two children stayed awake for two hours one night. We observed no change in this median during the first $24 \mathrm{~h}$. However, the median decreased to $3 \mathrm{~min}$ by $48 \mathrm{~h}$, a time similar to the children with no PSP $(p=0.28)$ (Table 2$)$. In the group with no PSP, none of the children had a history of awake episodes at night, but we observed an increase in this variable with a median of 5 min during the hospital stay.

Regarding daytime sleep (naps), the PSP group presented an average of one episode more than the no PSP group ( $p=0.01$ ) before hospitalization (Figure 4), and that influenced the total sleep time. However, during the in-hospital stay, the group with no PSP started to have daytime naps.

Furthermore, we observed that children from both groups woke up before the usual time at home (Figure 5). In the group with PSP, the mean time at 24 hours was 15 minutes earlier with no significant change at $48 \mathrm{~h}$ (mean 16, $p=0.96$ ). In the group with no PSP, the mean time at $24 \mathrm{~h}$ was earlier (20 $\mathrm{min}$ ) with no statistical significance $(p=0.62)$. However, at $48 \mathrm{~h}$, this time was significantly reduced, with a mean of $10 \mathrm{~min}(p=0.04)$.

Finally, in children with no PSP, $66.1 \%$ met at least two criteria to be considered as having impaired sleep during hospitalization at $24 \mathrm{~h}$. At $48 \mathrm{~h}$, this percentage was reduced to $33.8 \%(p=0.006)$. In contrast, $50 \%$ met the criteria for disturbed sleep at $24 \mathrm{~h}$ and $58.3 \%$ at $48 \mathrm{~h}$ in the group with PSP $(p=0.64)$.

Regarding the possible factors that modified the sleep pattern (Table 3), the parents' comments were related to the entry and exit of the healthcare personnel to the monitoring of vital signs and the patient's clinical condition. As this condition was present in all patients, it was not considered for the multivariable analysis.

For total sleep time, we found a significant difference related to the history of PSP and pulse oximetry and the use of an IV line sleep time, the latter during the $48 \mathrm{~h}$ stay. For sleep time, a drainage catheter was the main factor influencing the first $24 \mathrm{~h}$ of hospitalization.

\section{Discussion}

Our data support previous studies regarding the modifying effect of hospitalization on the sleep pattern ${ }^{3,5}$ and

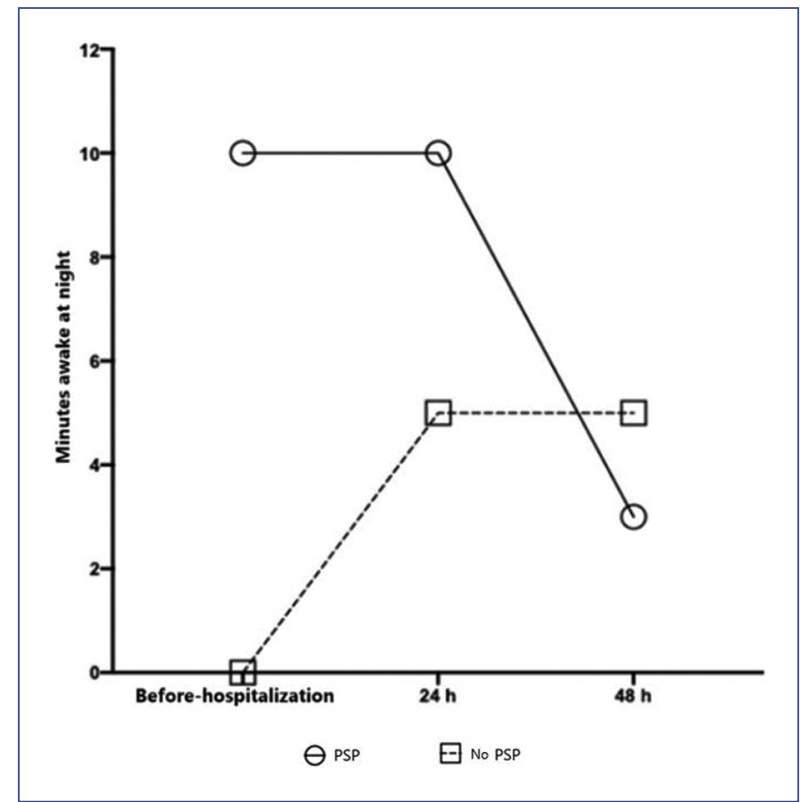

Figure 3. Minutes awake at night. Symbols show the median of each group. Mann Whitney's U-test between groups before hospitalization, $p=0.01$; at $24 \mathrm{~h}, \mathrm{p}=0.17$, and at $48 h, p=0.28$. PSP $(N=24)$; No PSP (N = 68).

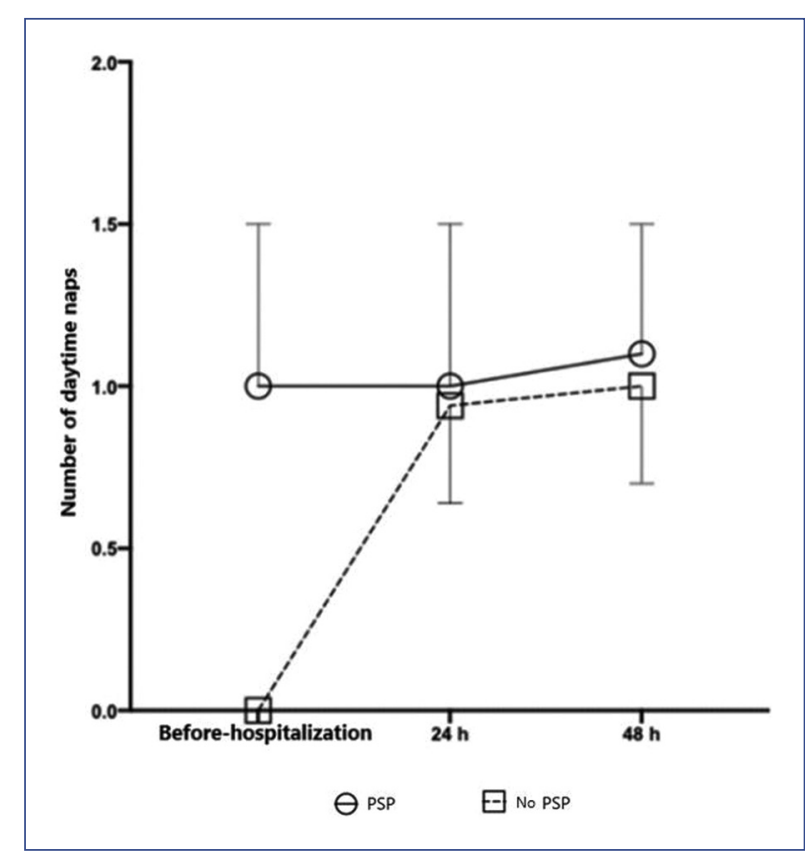

Figure 4. The number of daytime naps per day. Results are expressed as mean (symbols) \pm standard error (bars). Differences were observed only at baseline $(p<0.001)$ no statistically significant differences at 24 and $48 \mathrm{~h}$.

add a differential effect according to PSP history. Contrary to our initial hypothesis, hospitalization seems to affect the sleep pattern in children with no PSP and 
Table 3. Relationship between sleep time and risk factors

\begin{tabular}{|c|c|c|c|c|}
\hline Effect & After 24 hours of hospitaliz & tion & After 48 hours of hospital & \\
\hline Factors & Non-standardized beta $(95 \% \mathrm{Cl})$ & $p$-value & Non-standardized beta (95\% CI) & $p$-value \\
\hline $\begin{array}{l}\text { Total sleep hours } \\
\text { Previous sleep problems } \\
\text { Use of pulse oximeter } \\
\text { Intravenous line } \\
\text { Nebulization } \\
\mathrm{O}_{2} \text { with nasal tips } \\
\text { Use of monitor } \\
\text { Drains or catheters } \\
\text { Humidification tower }\end{array}$ & $\begin{array}{c}1.8(0.6-2.9) \\
2.5(0.8-4.3) \\
-2.2(-4--0.3) \\
-2.1(-3.8--0.3) \\
-4.7(-10.3-0.9) \\
0.8(-0.9-2.6) \\
-0.8(-3.1-1.4) \\
0.08(-1.5-1.7)\end{array}$ & $\begin{array}{c}<0.001 \\
<0.001 \\
0.02 \\
0.02 \\
0.10 \\
0.35 \\
0.47 \\
0.92\end{array}$ & $\begin{array}{c}1.7(-0.3-3.7) \\
1.1(-1.5-3.7) \\
-3.5(-6.6--0.4)) \\
-1.2(-3.9-1.5) \\
-5.4(-12.8-2) \\
0.9(-1.6-3.6) \\
4.6(1.7-7.6) \\
-1.5(-3.8-0.9)\end{array}$ & $\begin{array}{c}0.10 \\
0.39 \\
0.03 \\
0.18 \\
0.15 \\
0.46 \\
<0.001 \\
0.21\end{array}$ \\
\hline $\begin{array}{l}\text { Minutes to fall asleep } \\
\text { Previous sleep problems } \\
\text { Use of pulse oximeter } \\
\text { Intravenous line } \\
\text { Nebulization } \\
02 \text { with nasal tips } \\
\text { Use of monitor } \\
\text { Drains or catheters } \\
\text { Humidification tower }\end{array}$ & $\begin{array}{c}-12.1(-29.1-4.8) \\
-7(-31.5-17.4) \\
9.7(-16.9-36.3) \\
8.1(-16.8-33.1) \\
20.8(-58.9-100) \\
11.6(-0.9-2.6) \\
34.8(2.2-67.5) \\
1.6(-21.3-24.6)\end{array}$ & $\begin{array}{l}0.16 \\
0.57 \\
0.07 \\
0.11 \\
0.61 \\
0.36 \\
0.04 \\
0.89\end{array}$ & $\begin{array}{c}-7.1(-29.1-14.7) \\
20.5(-7.5-48.5) \\
-14.6(-48-18.9) \\
-12.7(-41.6-16.2) \\
-19.5(-98-59.1) \\
4.6(-24-32.1) \\
-1.09(-32.4-30.2) \\
5.8(-18.9-30.5)\end{array}$ & $\begin{array}{l}0.53 \\
0.15 \\
0.39 \\
0.38 \\
0.62 \\
0.77 \\
0.94 \\
0.64\end{array}$ \\
\hline
\end{tabular}

$\mathrm{Cl}$, confidence interval.

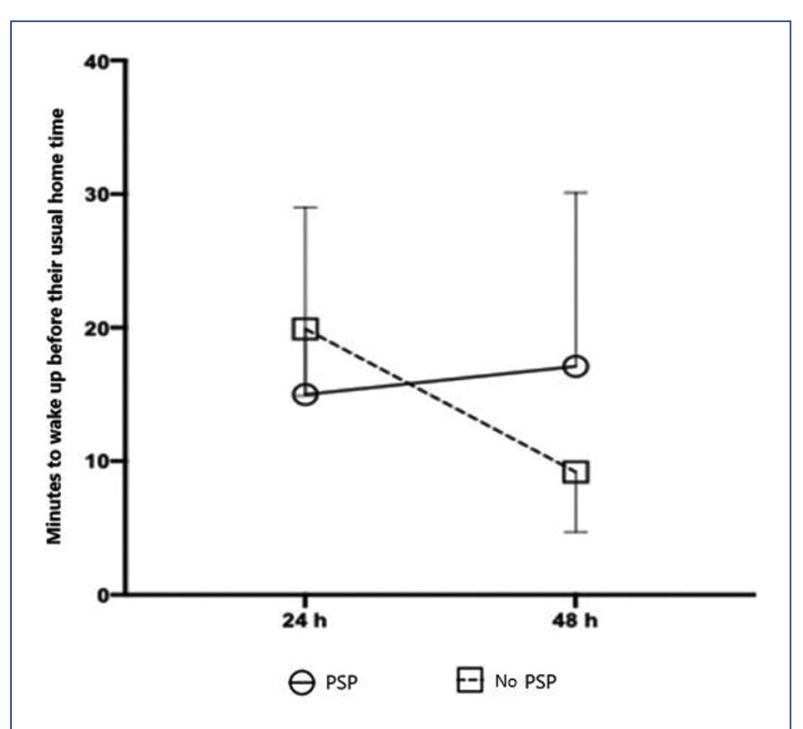

Figure 5. Wake-up time (minutes before their usual time at home). Results are expressed as median (symbols) \pm standard error (bars). Student's t-test between groups at $24 h, p=0.62$, and at $48 h, p=0.49$.

even improved the sleep pattern in those with PSP. The prevalence of PSP in the studied children was $20 \%$, slightly lower than that reported in other reviews ${ }^{2}$. In these children, evaluation of in-hospital monitoring during 48 hours confirmed an increase in sleep compared to that previously reported at home: $8.4 \mathrm{~h}$ for the first $24 \mathrm{~h}$, and $9.3 \mathrm{~h}$ for the $48 \mathrm{~h}$. This increase in total sleep time was associated with more nighttime awakenings and possible increased fatigue, as postulated by some authors ${ }^{6}$.

Usually, compensation for nighttime awakenings is the presence of short daytime sleeps (naps). These naps were observed in $49.1 \%$ of the children, with a higher frequency in those with a history of PSP. Although the medians were equal at one episode per day in both groups, there were up to three episodes in children with PSP. Crawford et al. found that $52 \%$ of their hospitalized patients reported taking a nap during the day. In the same study, it was found that these children were not getting an adequate amount of uninterrupted sleep ${ }^{5}$.

Hinds et al. and Linder and Christian reported 14 $(n=29)$ and 10.5-13 ( $n=15)$ nocturnal awakenings, respectively, in hospitalized children with cancer ${ }^{6,7}$. Our study found a lower number of nocturnal awakenings and detected that these were more frequent in children with PSP, with a median of one awakening and a maximum of up to eight episodes per night. In the group with no PSP, $50 \%$ of the children presented at least one awakening episode at night during the 24 and $48 \mathrm{~h}$ of hospitalization (median $24 \mathrm{~h}: 1$ [0-10] and $48 \mathrm{~h}: 1$ [0-8]), slightly lower than Crawford et al., who reported an average of 2.7 awakenings per night ${ }^{5}$. The explanation may be related to the quick attendance of the alarms at night, as they sound directly at the nursing station, which reduces the attendance time and, consequently, the number of awakenings ${ }^{8}$.

The noise level for adequate sleep recommended by the World Health Organization averages 30 
decibels ${ }^{9}$. Comparing this study with other previously reported findings, we found a resemblance in the environmental factors that influence nighttime awakenings. Of these factors, the most frequently mentioned are the sound of alarms and the presence of medical and nursing personnel in the room to evaluate the patient and monitoring vital signs. Some other factors found in these publications are missing home, concern about the school, uncomfortable beds, among others ${ }^{5,8,9}$.

One of our findings was that the time of awakening was earlier than the usual time at home in both groups. On average, both groups woke up 10 minutes earlier than usual, probably associated with the physicians' rounds and the blood and radiographic studies, usually performed between 6:00 and 7:00 am in the hospital.

In the study by Cidon and Alonso $(2013)^{10}$, the sleep habits of 98 cancer patients were analyzed using a sleep diary. They reported a $43 \%$ prevalence of sleep pattern disturbances. They observed troubles falling asleep in $54 \%$, trouble staying asleep in $18 \%$, and early awakenings in $16 \%$. Wesselius et al. (2017), in the Netherlands, found that hospitalized patients sleep on average 83 minutes less than they do at home. This result was mainly caused by premature awakenings of the participants earlier than usual (mean of $44 \mathrm{~min})^{3}$. In our study, although early awakenings represented only 10 minutes, the leading causes for sleep pattern disturbances were noise and interruptions by the medical staff (sounding of alarms, entry and exit of medical personnel, and the performance of nebulization and pulmonary physiotherapy).

The relationship between sleep and the immune system is of particular interest. The mechanism by which infections tend to modify the sleep pattern is currently not well understood ${ }^{9}$. Regardless, one hypothesis is that the acute inflammatory response produced by infectious processes alters the expression of endogenous immunomodulatory substances (cytokines), resulting in sleep disturbance. These cytokines include tumor necrosis factor, interferons, and interleukins produced by the host during infection, for which it is believed that they may play a direct role in regulating sleep ${ }^{11}$.

Sleep fragmentation increases cortisol release, increases stress, alters mood, affects executive attention and active memory ${ }^{8,12}$. On the contrary, sleeping well improves pain tolerance and reduces analgesic requirements in children ${ }^{9}$.
Some of the limitations of our study are the sample size and that we conducted the study in only one medical unit. Another limitation of our study was that the instrument used to measure sleep quality might have been inaccurate; a better option would have been a sleep-sensor or even polysomnography ${ }^{13}$. Finally, it appears that hospitalization improved the sleep pattern in the PSP group. Unfortunately, as no subsequent follow-up was performed, this hypothesis cannot be confirmed.

Children with PSP are usually the most affected during hospitalization. Therefore, special attention should be paid to avoid perpetuating sleep disturbances. We recommend screening every child before admission to detect vulnerable patients and, thus, be more careful with the schedules of medical visits and procedures to avoid further alteration.

This study reinforces that the quality and quantity of sleep in children are affected during hospitalization. Our results support that hospitalization increases the time needed to fall asleep, the number of daytime naps, and nighttime awakenings, with a consequent reduction in total sleep time in children with no PSP.

In children with PSP, the effect of hospitalization on sleep pattern was less evident. Even sleep hygiene slightly improved in these children, which could support some problems given by the conditions at home.

We recommend the sleep assessment in all hospitalized children and consider strategies to promote restorative sleep times, minimizing as much as possible the procedures to avoid its interruption.

\section{Ethical disclosures}

Protection of human and animal subjects. The authors declare that no experiments were performed on humans or animals for this study.

Confidentiality of data. The authors declare that they have followed the protocols of their work center on patient data publication.

Right to privacy and informed consent. The authors have obtained the written informed consent of the patients or subjects mentioned in the article. The corresponding author has this document.

\section{Conflicts of interest}

The authors declare no conflict of interest. 


\section{Funding}

None.

\section{Acknowledgments}

We thank the family members of our patients for their support.

\section{References}

1. Paruthi S, Brooks LJ, D'Ambrosio C, Hall WA, Kotagal S, Lloyd RM et al. Recommended amount of sleep for pediatric populations: a consensus statement of the American Academy of Sleep Medicine. J Clin Sleep Med. 2016;12:785-6.

2. Hiscock H, Davey MJ. Sleep disorders in infants and children. J Paediatr Child Health. 2018;54:941-4

3. Wesselius HM, van den Ende ES, Alsma J, Ter Maaten J, Schuit S, Stassen $\mathrm{P}$, et al. Quality and quantity of sleep and factors associated with sleep disturbance in hospitalized patients. JAMA Intern Med. 2018;178:1201-8
4. Sadeh A. A brief screening questionnaire for infant sleep problems: validation and findings for an internet sample. Pediatrics. 2004;113:e570-7.

5. Crawford S, Utt A, Beebe C, Armbruster R, Fisher A, Olney A, et al. Quality of sleep in a pediatric hospital: a descriptive study based on an assessment of interruptions, perceptions, and the environment. J Nurs Adm. 2019;49:273-9.

6. Linder LA, Christian BJ. Nighttime sleep disruptions, the hospital care environment, and symptoms in elementary school-age children with cancer. Oncol Nurs Forum. 2012;39:553-61.

7. Hinds PS, Hockenberry M, Rai SN, Zhang L, Razzouk BI, McCarthy K, et al. Nocturnal awakenings, sleep environment interruptions, and fatigue in hospitalized children with cancer. Oncol Nur Forum. 2007;34:393-402.

8. Stickland A, Clayton E, Sankey R, Hill CM. A qualitative study of sleep quality in children and their resident parents when in hospital. Arch Dis Child. 2016;101:546-51.

9. Bevan R, Grantham-Hill S, Bowen R, Clayton E, Grice H, Venditti HC, et al. Sleep quality and noise: comparisons between hospital and home settings. Arch Dis Child. 2019;104:147-51.

10. Cidon EU, Alonso P. Pilot study of insomnia prevalence in cancer survivors. WebmedCentral CANCER. 2013;4:1-6

11. Bryant PA, Trinder J, Curtis N. Sick and tired: does sleep have a vita role in the immune system? Nat Rev Immunol. 2004;4:457-67.

12. Growdon ME, Inouye SK. Minimizing sleep disruption for hospitalized patients: a wake-up call. JAMA Intern Med. 2018;178:1208-9.

13. Coleman RM, Roffwarg HP, Kennedy SJ, Guilleminault C, Cinque J, Cohn MA, et al. Sleep-wake disorders based on a polysomnographic diagnosis. A national cooperative study. JAMA. 1982;247:997-1003. 